\title{
Metabolism of DD-2,6-Diaminopimelic Acid by a Diaminopimelate-requiring Mutant of Bacillus megaterium
}

\author{
By FARANGIS SALEH* AND P. J. WHITE \\ Department of Microbiology, The University, Western Bank, Sheffield S10 $2 T N$
}

(Received 20 February 1979)

\begin{abstract}
A diaminopimelate-requiring mutant of Bacillus megaterium was shown to lack the enzyme $N$-acetyl-LL-diaminopimelate deacylase. By repeated subculture of this mutant, a secondstage mutant was derived that could grow slowly in minimal defined medium supplemented with DD-diaminopimelate alone. After growth in such medium, the peptidoglycan of the wall still contained mainly meso- and LL-diaminopimelate; radioactivity from DD-diamino$\left[{ }^{14} \mathrm{C}\right]$ pimelate entered peptidoglycan (as diamino $\left[{ }^{14} \mathrm{C}\right]$ pimelate) and protein (as $\left[{ }^{14} \mathrm{C}\right]$ lysine) to similar extents.
\end{abstract}

\section{INTRODUCTION}

The DD-isomer of 2,6-diaminopimelic acid $\left(\mathrm{A}_{2} \mathrm{pm}\right)$ accounted for about $7 \%$ of the total $\mathrm{A}_{2} \mathrm{pm}$ present in acid-hydrolysates of walls of Bacillus megaterium NCIB 7581 (Day \& White, 1977). This organism slowly took up DD- $\left[{ }^{14} \mathrm{C}\right] \mathrm{A}_{2} \mathrm{pm}$ during growth and most of the radioactivity incorporated into peptidoglycan was in the form of meso- $\left[{ }^{14} \mathrm{C}\right] \mathrm{A}_{2} \mathrm{pm}$ (Day \& White, 1979), suggesting that DD- and meso- $\mathrm{A}_{2} \mathrm{pm}$ are enzymically interconvertible.

In the present study, a diaminopimelate-requiring mutant of $B$. megaterium was grown with DD- $\mathrm{A}_{2} \mathrm{pm}$ as the sole source of this amino acid. The meso- and LL-isomers of $\mathrm{A}_{2} \mathrm{pm}$ still predominated in the peptidoglycan, and when $\mathrm{DD}-\left[{ }^{14} \mathrm{C}\right] \mathrm{A}_{2} \mathrm{pm}$ was given, $\left[{ }^{14} \mathrm{C}\right]$ lysine was found in the protein, which implies that free meso- $\mathrm{A}_{2} \mathrm{pm}$ must have been formed from the DD-A $\mathrm{A}_{2} \mathrm{pm}$.

\section{METHODS}

Organisms. Bacillus megaterium NCIB 7581 and a diaminopimelate-requiring mutant of this strain (NCIB 11251; here called mutant SW1) have been described by Saleh \& White (1976). A second-stage mutant, derived from mutant SW1 (see below) and called mutant SW2, could grow on DD-A pm as well as the other two isomers of $\mathbf{A}_{2} \mathrm{pm}$. All were maintained on slopes of nutrient agar or of medium FGB (see below) with synthetic $\mathrm{A}_{2} \mathrm{pm}\left(100 \mathrm{mg} \mathrm{l}^{-1}\right)$ added for the mutants; incubation was at $37^{\circ} \mathrm{C}$ overnight, and stock cultures were kept at $2^{\circ} \mathrm{C}$.

Media. All media were made with glass-distilled water. Medium FGB (Saleh \& White, 1976) was used except where stated otherwise, with glycerol $(1 \%, \mathrm{w} / \mathrm{v})$ as the main source of carbon. Trisodium citrate dihydrate $\left(20 \mathrm{mg} \mathrm{l}^{-1}\right.$ ) was generally added. Medium A (White, 1972) supplemented with biotin $\left(20 \mu \mathrm{g} \mathrm{l}^{-1}\right)$ and sodium citrate (as above) was used in some experiments. Difco agar $(1.5 \%, \mathrm{w} / \mathrm{v})$ was added for solid media.

Conditions of growth. Organisms were grown at $37^{\circ} \mathrm{C}$ in shaken flasks and growth was assessed from turbidity measurements as described previously (White, 1972).

Assays for isomers of $A_{2} p m$. The procedures described by Day \& White (1979) were used.

Preparation of isomers of $A_{2}$ pm. Unlabelled isomers were isolated as described by Day \& White (1977). Isomers of $\left[{ }^{14} \mathrm{C}\right] \mathrm{A}_{2} \mathrm{pm}$ were separated essentially as described by Day \& White (1979). To ensure the absence of meso- $\left[{ }^{14} \mathrm{C}\right] \mathrm{A}_{2} \mathrm{pm}$, the $\mathrm{DD}-\left[{ }^{14} \mathrm{C}\right] \mathrm{A}_{2} \mathrm{pm}$ was incubated with diaminopimelate decarboxylase for a second time, after the separation from $L L-\left[{ }^{14} \mathrm{C}\right] \mathrm{A}_{2} \mathrm{pm}$ by chromatography.

* Present address: Medical Center of Iran, Department of Microbiology, Vanak Square, Gandi Street, Tehran, Iran. 
Measurement of radioactivity. Samples in the scintillation fluid of Bray (1960) were counted by the channels ratio method in a Nuclear-Chicago apparatus (Isocap/300). Developed chromatograms were placed in contact with Kodirex X-ray film for appropriate times to locate labelled compounds. Radioactive areas were counted by cutting strips of the chromatograms into pieces and counting each piece.

Chromatography. Descending chromatograms on Whatman no. 1 paper were developed in solvent A (methanol/water/10 $\mathrm{M}-\mathrm{HCl} /$ pyridine; 80:17.5:2.5:10, by vol.). This separates $\mathrm{LL}-\mathrm{A}_{2} \mathrm{pm}$ from the mesoand DD-isomers, which run more slowly and almost together (Rhuland et al., 1955); lysine runs well in front of $L L-A_{2} \mathrm{pm}$. Amino acids were detected by dipping the dried paper in ninhydrin $(0 \cdot 1 \%$ in acetone), drying and then heating at about $80{ }^{\circ} \mathrm{C}$ for $5 \mathrm{~min}$.

Isolation and hydrolysis of walls. The procedures of Day \& White (1977) were used. Before assay of isomers of $\mathrm{A}_{2} \mathrm{pm}$ in hydrolysates, the $\mathrm{A}_{2} \mathrm{pm}$ was adsorbed on Dowex 50 and eluted with aqueous ammonia as described by Day \& White (1977).

Isolation of peptidoglycan and material dissolved by trypsin (protein). The slightly modified procedure (Wilkinson \& White, 1973) of Park \& Hancock (1960) was used to isolate peptidoglycan and protein (material dissolved by trypsin) from organisms grown with $\left[{ }^{14} \mathrm{C}\right] \mathrm{A}_{2} \mathrm{pm}$. Radioactivity was measured in the supernatant liquid left after each step in the treatment, and in the acid-hydrolysate of the final solid residue (peptidoglycan).

Assay of N-acetyl-LL-diaminopimelate deacylas?. Bacillus megaterium 7581 and mutant SW1 were grown at $37^{\circ} \mathrm{C}$ in medium $\mathrm{A} 1$, with synthetic $\mathrm{A}_{2} \mathrm{pm}\left(100 \mu \mathrm{g} \mathrm{ml}^{-1}\right)$ added for both organisms; the wild-type was also grown in the absence of $\mathrm{A}_{2} \mathrm{pm}$. Bacteria were harvested during the exponential growth phase, washed and crude extracts prepared as for the purification of diaminopimelate epimerase (White et al., 1969). The deacylase was measured as described by Sundharadas \& Gilvarg (1967), except that formation of $\mathrm{A}_{2} \mathrm{pm}$ was usually determined by the method of Work (1957) as follows: samples $(100 \mu 1)$ from the enzymic assay mixture were added to tubes containing acetic acid $(0.8 \mathrm{ml})$ at room temperature, and then the ninhydrin reagent $(0.1 \mathrm{ml})$ was added. Absorbance at $440 \mathrm{~nm}$ was measured after incubating the tubes at $37^{\circ} \mathrm{C}$ for $90 \mathrm{~min}$. Assay mixtures without enzyme, or without substrate, or with $\mathrm{A}_{2} \mathrm{pm}$ in place of substrate were incubated as controls. $N$-Acetyl-LL-diaminopimelate and lysine gave no colour in this assay.

Accumulation of $N$-acetyl-LL-diaminopimelate by mutant $\mathrm{SW}$. Organisms were harvested after incubation for $3 \mathrm{~d}$ at $37^{\circ} \mathrm{C}$ in medium $\mathrm{A} 1$ plus synthetic $\mathrm{A}_{2} \mathrm{pm}\left(40 \mathrm{mg} \mathrm{l}^{-1}\right)$. With this limiting concentration of $\mathrm{A}_{2} \mathrm{pm}$, the stationary phase had been reached after $1 \mathrm{~d}$. Pool amino acids were extracted with $0.25 \mathrm{M}$-perchloric acid as described by Tempest et al. (1970). $N$-Acetyl-LL-diaminopimelate in this extract was recognized by its behaviour in the colorimetric assay of Sundharadas \& Gilvarg (1967), which involves heating at $100^{\circ} \mathrm{C}$ with acidic ninhydrin. Maximum absorbance (at $420 \mathrm{~nm}$ ) is produced after $20 \mathrm{~min}$ with $N$-acetyl-LL-diaminopimelate, $\mathrm{A}_{2}$ pm or lysine, but whereas $\mathrm{A}_{2} \mathrm{pm}$ and lysine give about $90 \%$ of maximum absorbance after heating for only $5 \mathrm{~min}, \mathrm{~N}$-acetyl-LL-diaminopimelate gives only 14 to $25 \%$ of the maximum in this time. The pool extract contained material which gave a peak on the amino-acid analyser trace near the position of $\alpha$-aminoadipic acid (as does authentic $N$-acetyl-LL-diaminopimelate) but no $\mathrm{A}_{2} \mathrm{pm}$ was present. After heating the pool extract at $105^{\circ} \mathrm{C}$ for $18 \mathrm{~h}$ in $6 \mathrm{M}-\mathrm{HCl}$, the peak near $\alpha$-aminoadipate had disappeared and a peak in the position of $\mathrm{A}_{2} \mathrm{pm}$ was found.

Isolation of a second-stage mutant able to grow on $\mathrm{DD}-A_{2} p m$. A large inoculum of mutant SW1 (about $10^{7}$ colony-forming units) was plated on medium FGB containing DD-A $\mathrm{pm}\left(100 \mu \mathrm{g} \mathrm{ml}^{-1}\right)$. After incubation at $37^{\circ} \mathrm{C}$ for $3 \mathrm{~d}$ several very small colonies appeared. Ten of these were subcultured on to the same medium. Only three continued to grow. After subculturing each of these five times on the same medium all three were separately transferred to liquid medium FGB containing DD-A $A_{2} \mathrm{pm}\left(100 \mu \mathrm{g} \mathrm{ml}^{-1}\right)$. Only one culture grew within $2 \mathrm{~d}$; these organisms were called mutant SW2.

Chemicals. $N$-Acetyl-LL-diaminopimelate was prepared from LL-A $A_{2} \mathrm{pm}$ as described by Ward (1975). Sources of $\mathrm{A}_{2} \mathrm{pm}$ are given by Day \& White (1979).

\section{RESULTS}

\section{Identification of the block in synthesis of $A_{2}$ pm in mutant SW 1}

Since mutant SW1 did not require methionine or threonine and grew in medium FGB supplemented with LL- $\mathrm{A}_{2} \mathrm{pm}$, the block in the synthesis of this amino acid must presumably occur at one (or more) of the five enzymic reactions that lead to the conversion of $L$-aspartic $\beta$-semialdehyde into $\mathrm{LL}-\mathrm{A}_{2} \mathrm{pm}$ (see Ward, 1975). The frequency of reversion of mutant SW1 (to regain ability to grow on medium FGB without $\mathrm{A}_{2} \mathrm{pm}$ after overnight incubation at $37^{\circ} \mathrm{C}$ ) was 1 in $10^{8}$ colony-forming units plated, which is consistent with a single point mutation causing the block in synthesis of $\mathrm{A}_{2} \mathrm{pm}$. 
Because of the relative ease of preparing the substrate and doing the assay, the first enzyme measured in extracts of mutant and wild-type was $N$-acetyl-LL-diaminopimelate deacylase. This enzyme was present in the wild-type and had the same activity $\left[5 \mathrm{nmol} \mathrm{min}^{-1}\right.$ (mg protein $)^{-1}$ ] whether the organisms were grown with or without $\mathrm{A}_{2} \mathrm{pm}$, but the enzyme was not detected in three separate extracts of mutant SW1. The mutant extract did not inhibit or enhance the deacylase activity of wild-type extract when equal volumes of extracts of wild-type and mutant (each about $10 \mathrm{mg}$ protein $\mathrm{ml}^{-1}$ ) were mixed before assay. The mutant extract did contain diaminopimelate decarboxylase $\left[14 \mathrm{nmol} \mathrm{min}^{-1}(\mathrm{mg} \text { protein })^{-1}\right.$; assayed manometrically as described by White, 1971], but this activity was no higher than in the parent strain and was measurable only when pyridoxal phosphate was present in the assay system. No lysine (or $\mathrm{A}_{2} \mathrm{pm}$ ) was detected on chromatograms (solvent $\mathrm{A}$ ) of deacylase assay mixtures (which did not contain pyridoxal phosphate) after incubation with mutant extracts, and there was no disappearance of $\mathrm{A}_{2} \mathrm{pm}$ when this amino acid and mutant extract were added to a deacylase assay mixture lacking the normal substrate. Hence, decarboxylation or other metabolism of $\mathrm{A}_{2} \mathrm{pm}$ (the product assayed when measuring the deacylase) by the mutant extract did not account for the failure to detect the enzyme in mutant SW1.

Cultures of mutant SW1 were grown at $37^{\circ} \mathrm{C}$ in medium $\mathrm{A} 1$ and $\mathrm{A} 2$ with a limiting concentration $\left(40 \mu \mathrm{g} \mathrm{ml}^{-1}\right)$ of synthetic $\mathrm{A}_{2} \mathrm{pm}$. No $N$-acetyldiaminopimelate was detected in culture filtrates at any stage up to $2 \mathrm{~d}$ in the stationary phase, even when the filtrates were concentrated about 10 -fold by evaporation. However, $N$-acetyldiaminopimelate was found in the free amino acid pool of late-stationary phase organisms (see Methods), when the proportion of revertants (independent of $\mathrm{A}_{2} \mathrm{pm}$ ) was still negligible; its concentration was about $0.02 \mathrm{~mm}$, but it was absent from the pool at earlier stages of growth. The presence of this metabolic intermediate shows that mutant SW1 must contain all the enzymes needed for its synthesis, so that, of the enzymes concerned in formation of $\mathrm{A}_{2} \mathrm{pm}$, only the deacylase is absent from the mutant.

\section{Properties of mutant SW2}

Mutant SW2 (see Methods) grew in defined medium supplemented with any one of the isomers of $\mathrm{A}_{2} \mathrm{pm}$, though growth was quicker and heavier when meso- or LL-A $\mathrm{A}_{2} \mathrm{pm}$ was supplied (Fig. 1). The organisms (as judged by phase-contrast microscopy) resembled the wild-type and mutant SW1, and their appearance was unaltered by growth with DD-A.pm. It is very unlikely that mutant SW2 was really growing on meso- or LL-A $\mathrm{Am}_{2}$ present as impurities in the DD-A.2 $\mathrm{pm}$. From its optical rotation and other properties (Saleh \& White, 1976), the DD- $\mathrm{A}_{2} \mathrm{pm}$ must have been at least $95 \%$ (w/w) pure. No LL-isomer could be detected in the DD-A $\mathrm{A}_{2} \mathrm{pm}$ by paper chromatography, and growth of mutant SW1 with DD- $\mathrm{A}_{2} \mathrm{pm}$ $\left(400 \mu \mathrm{g} \mathrm{ml}^{-1}\right)$ was very sparse, whereas mutant SW2 grew to $0.5 \mathrm{mg}$ dry wt $\mathrm{ml}^{-1}$ when the same DD-A 2 pm was supplied at $100 \mu \mathrm{g} \mathrm{ml}^{-1}$.

\section{Metabolism of $\mathrm{DD}-A_{2} p m$}

Walls of $B$. megaterium 7581 and of mutants SW1 and SW2 were isolated after growth with various supplements to the medium and assayed for the three isomers of $A_{2}$ pm (Table 1). In every case the meso-isomer remained predominant and LL-A $\mathrm{A}_{2} \mathrm{pm}$ was also present. Even when mutant SW2 was grown with DD- $\mathrm{A}_{2} \mathrm{pm}$, this isomer constituted only a small part of the total $\mathrm{A}_{2} \mathrm{pm}$ in the wall.

To trace the fate of $\mathrm{DD}-\mathrm{A}_{2} \mathrm{pm}$, medium FGB containing DD- $\mathrm{A}_{2} \mathrm{pm}$ was inoculated with mutant SW2, incubated at $37^{\circ} \mathrm{C}$, and DD- $\left[{ }^{14} \mathrm{C}\right] \mathrm{A}_{2} \mathrm{pm}$ was added when the medium had just become turbid. When growth stopped, the bacteria were harvested and peptidoglycan and material dissolved by trypsin (i.e. derived from protein) were isolated and hydrolysed with acid (see Methods). Radioactivity was measured at each step in the isolation of peptidoglycan and in the hydrolysates (Table 2). Far more radioactivity was incorporated by the organisms than could possibly have been present as contaminating LL- or meso- $\left[{ }^{14} \mathrm{C}\right] \mathrm{A}_{2} \mathrm{pm}$. A 


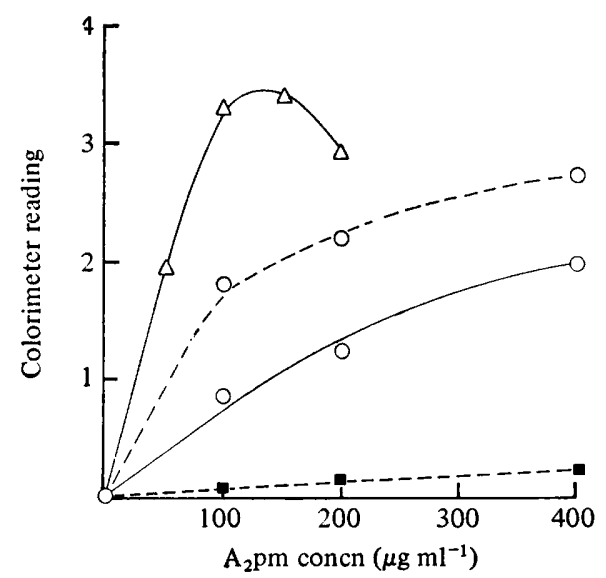

Fig. 1. Requirement for $A_{2} \mathrm{pm}$ by mutants SW1 and SW2. Organisms were grown in medium FGB at $37^{\circ} \mathrm{C}$ with different concentrations of meso- or DD-A $\mathrm{A}_{2} \mathrm{pm}$ and turbidity was measured at intervals. Growth of organisms after $21 \mathrm{~h}(-)$ or after $45 \mathrm{~h}(---): \triangle$, mutant SW1 with meso- $\mathrm{A}_{2} \mathrm{pm}$ (the response of mutant SW2 to meso- $\mathrm{A}_{2} \mathrm{pm}$ was similar); $\square$, mutant SW1 with DD-A $\mathrm{A}_{2} \mathrm{pm}$; $\mathrm{O}$, mutant SW2 with DD-A $\mathrm{A}_{2} \mathrm{pm}$. The responses of both mutants to LL-A $\mathrm{A}_{2} \mathrm{pm}$ resembled their responses to the meso-isomer.

\section{Table 1. Proportions of isomers of $A_{2} p m$ in walls of B. megaterium 7581 and mutant strains}

Walls of $B$. megaterium 7581 and the mutants SW1 and SW2 were isolated after growth of the organisms in medium FGB with the supplements indicated (each at $100 \mu \mathrm{g} \mathrm{ml}^{-1}$ ). Isomers of $\mathrm{A}_{2} \mathrm{pm}$ were measured enzymically (see Methods). The colour produced in the assay for residual DD- $\mathrm{A}_{2}$ pm was abnormal (slightly brown rather than yellow) because of the large excess of lysine present. Hence, the actual proportion of DD-A $\mathrm{A}_{2} \mathrm{pm}$ in the walls is probably smaller than given in this Table.

\begin{tabular}{|c|c|c|c|c|}
\hline \multirow[b]{2}{*}{ Organism } & \multirow{2}{*}{$\begin{array}{c}\text { Total } \mathrm{A}_{2} \mathrm{pm} \\
{\left[\mu \mathrm{g}(\mathrm{mg} \text { wall })^{-1}\right]}\end{array}$} & \multicolumn{3}{|c|}{$\begin{array}{c}\text { Isomers of } \mathbf{A}_{2} \mathrm{pm} \text { present } \\
\left(\% \text { of total } \mathbf{A}_{2} \mathrm{pm}\right)\end{array}$} \\
\hline & & meso- & LL- & DD- \\
\hline $\begin{array}{l}\text { B. megaterium } 7581 \\
\text { (grown without } \mathrm{A}_{2} \mathrm{pm} \text { ) }\end{array}$ & 72 & 60 & 18 & 21 \\
\hline $\begin{array}{l}\text { B. megaterium } 7581 \\
\text { (grown with } \text { meso- } \mathrm{A}_{2} \mathrm{pm} \text { ) }\end{array}$ & 93 & 69 & 18 & 13 \\
\hline $\begin{array}{l}\text { Mutant SW1 } \\
\text { (grown with meso-A } \mathrm{A}_{2} \mathrm{pm} \text { ) }\end{array}$ & 93 & 68 & 18 & 14 \\
\hline $\begin{array}{l}\text { Mutant SW2 } \\
\text { (grown with meso- } \mathrm{A}_{2} \mathrm{pm} \text { ) }\end{array}$ & 91 & 70 & 20 & 11 \\
\hline $\begin{array}{l}\text { Mutant SW2 } \\
\left.\text { (grown with DD-A } \mathrm{A}_{2} \mathrm{pm}\right)\end{array}$ & 72 & 65 & 18 & 17 \\
\hline
\end{tabular}

preliminary experiment showed that relatively little of the ${ }^{14} \mathrm{C}$ taken up could be extracted by cold trichloroacetic acid (i.e. was present in the free amino acid pool); most ${ }^{14} \mathrm{C}$ was present in peptidoglycan and in protein. The identities of labelled compounds in the hydrolysates were determined by chromatography and autoradiography. In the peptidoglycan the only labelled compounds found were isomers of $\mathrm{A}_{2} \mathrm{pm}$ (LL- and meso-/DD-) and in the protein fraction only radioactive lysine and traces of $\mathrm{A}_{2} \mathrm{pm}$ were found. The proportions of the individual isomers of $\left[{ }^{14} \mathrm{C}\right] \mathrm{A}_{2} \mathrm{pm}$ were not determined in the peptidoglycan, but it seems reasonable to suppose that they were about the same as given in Table 1 (for unlabelled walls), because autoradiography showed that less $L L-\left[{ }^{14} \mathrm{C}\right] \mathrm{A}_{2} \mathrm{pm}$ than meso- $\left[{ }^{14} \mathrm{C}\right] \mathrm{A}_{2} \mathrm{pm}$ had been formed, and the presence of $\left[{ }^{14} \mathrm{C}\right] \mathrm{lysine}$ showed that free meso $-\left[{ }^{14} \mathrm{C}\right] \mathrm{A}_{2} \mathrm{pm}$ had also been produced; this isomer is the only substrate that is attacked by diaminopimelate decarboxylase to give lysine (Work, 1962).

Similar experiments were done with mutant SW2 grown with meso $-\left[{ }^{14} \mathrm{C}\right] \mathrm{A}_{2} \mathrm{pm}$ and with 
Table 2. Uptake of radioactivity and its distribution during fractionation of the organisms after growth of mutants $\mathrm{SW} 1$ and $\mathrm{SW} 2$ with $\left[{ }^{14} \mathrm{C}\right] A_{2} p m$

Cultures were grown at $37{ }^{\circ} \mathrm{C}$ in shaken flasks containing $30 \mathrm{ml}$ medium FGB with synthetic $\left[{ }^{14} \mathrm{C}\right]-$ $\mathrm{A}_{2}$ pm or meso- $\left[{ }^{14} \mathrm{C}\right] \mathrm{A}_{2} \mathrm{pm}$ (each at $100 \mu \mathrm{g} \mathrm{ml}{ }^{-1}$ ) or in $10 \mathrm{ml}$ medium FGB with DD- $\left[{ }^{14} \mathrm{C}\right] \mathrm{A}_{2}$ pm $(50 \mu \mathrm{g}$ $\mathrm{ml}^{-1}$ ). The total uptake of $\mathbf{A}_{2} \mathrm{pm}$ was measured as the difference between the radioactivity added and that left in the culture filtrate when the organisms were harvested. Counts measured during fractionation were corrected to the same initial specific activity [520 d.p.m. $\left.\left(\mu \mathrm{g} \mathrm{A}_{2} \mathrm{pm}\right)^{-1}\right]$ for each experiment.

\begin{tabular}{|c|c|c|c|}
\hline & $\begin{array}{c}\text { SW1 } \\
+ \text { synthetic } \\
{\left[{ }^{14} \mathrm{C}\right] \mathrm{A}_{2} \mathrm{pm}}\end{array}$ & $\begin{array}{c}\mathrm{SW} 2 \\
+m e s o-\left[{ }^{14} \mathrm{C}\right] \mathrm{A}_{2} \mathrm{pm}\end{array}$ & $\begin{array}{c}\mathrm{SW} 2 \\
+\mathrm{DD}-\left[{ }^{14} \mathrm{C}\right] \mathrm{A}_{2} \mathrm{pm}\end{array}$ \\
\hline $\begin{array}{l}\text { Total uptake of } \mathrm{A}_{2} \mathrm{pm}[\mu \mathrm{g} \text { (mg dry wt } \\
\left.\text { organisms) }^{-1}\right]\end{array}$ & 79 & 55 & 53 \\
\hline $\begin{array}{l}\text { Percentage }(w / w) \text { of added }\left[{ }^{14} \mathrm{C}\right] \mathrm{A}_{2} \mathrm{pm} \\
\text { taken up }\end{array}$ & 77 & 48 & 48 \\
\hline \multicolumn{4}{|l|}{$\begin{array}{l}\text { Radioactivity recovered in fractions } \\
\text { [corrected d.p.m. (mg dry wt organisms) }\end{array}$} \\
\hline Cold trichloroacetic acid extract & 7700 & 2350 & ND \\
\hline \multicolumn{4}{|l|}{ Ethanol extract } \\
\hline $\begin{array}{l}\text { Hot trichloroacetic acid extract } \\
\text { Water wash }\end{array}$ & 1900 & 895 & 892 \\
\hline Material dissolved by irypsin (protein) & $\begin{array}{c}11000^{*} \\
(33 \mu \mathrm{g} \text { lysine })\end{array}$ & $\begin{array}{c}6090^{*} \\
(18 \mu \mathrm{g} \text { lysine })\end{array}$ & $\begin{array}{c}4750^{*} \\
(14 \mu \mathrm{g} \text { lysine })\end{array}$ \\
\hline Water wash & 400 & 213 & 478 \\
\hline Hydrolysed residue (peptidoglycan) & $\begin{array}{c}10100 \dagger \\
\left(19 \mu \mathrm{g} \mathrm{A} \mathrm{A}_{2} \mathrm{pm}\right)\end{array}$ & $\begin{array}{c}9610 \dagger \\
\left(18 \mu \mathrm{g} \mathrm{A} \mathrm{A}_{2} \mathrm{pm}\right)\end{array}$ & $\begin{array}{c}7490 \dagger \\
\left(14 \mu \mathrm{g} \mathrm{A_{2 }} \mathrm{pm}\right)\end{array}$ \\
\hline
\end{tabular}

mutant SW1 grown with synthetic $\left[{ }^{14} \mathrm{C}\right] \mathrm{A}_{2} \mathrm{pm}$ (Table 2). Again, $\left[{ }^{14} \mathrm{C}\right] \mathrm{A}_{2} \mathrm{pm}$ was the only major radioactive component of the peptidoglycan, and $\left[{ }^{14} \mathrm{C}\right]$ lysine alone was found in the protein.

The amounts of $\mathrm{A}_{2} \mathrm{pm}$ taken up (as measured by disappearance of radioactivity from the medium) in supporting growth of $1 \mathrm{mg}$ dry wt of mutant SW2 were $55 \mu \mathrm{g}$ and $53 \mu \mathrm{g}$ with the meso- and DD-isomers, respectively. Day \& White (1979) calculated that about $25 \mu \mathrm{g}$ $\mathrm{A}_{2} \mathrm{pm}$ and $25 \mu \mathrm{g}$ lysine might be needed for growth of $1 \mathrm{mg}$ dry wt of $B$. megaterium organisms. The amounts of these two amino acids actually incorporated by mutant SW2 are fairly close to this estimate.

\section{DISCUSSION}

The $\mathrm{A}_{2}$ pm-requiring mutant (SW1) of B. megaterium isolated by Saleh \& White (1976) lacks the enzyme $N$-acetyl-LL-diaminopimelate deacylase. This enzyme was detected in the wild-type (grown without $\mathrm{A}_{2} \mathrm{pm}$ ) with an activity just enough to produce LL- $\mathrm{A}_{2} \mathrm{pm}$ (assuming $60 \mu \mathrm{g}$ is needed for growth of $1 \mathrm{mg}$ of new organisms, see Results) at a rate sufficient to allow the observed doubling time of $90 \mathrm{~min}$ in medium $\mathrm{Al}$ at $37^{\circ} \mathrm{C}$. Growth of the wild-type with $\mathrm{A}_{2} \mathrm{pm}$ did not repress the enzyme, and so it is very unlikely that the enzyme was absent from mutant SW1 as a consequence of the presence of $\mathrm{A}_{2} \mathrm{pm}$ in the medium.

No previous reports have been made of $\mathrm{DD}-\mathrm{A}_{2} \mathrm{pm}$ being effective as a bacterial growth factor. The mutant SW2 grew more slowly with this isomer than with meso- or LL-A 2 pm, presumably because of a slower rate of uptake of the DD-isomer, or because of a slow rate of isomerization of $\mathrm{DD}-\mathrm{A}_{2} \mathrm{pm}$ to meso- $\mathrm{A}_{2} \mathrm{pm}$, which is needed as a component of peptidoglycan and as a precursor of lysine. The rate of this isomerization for the observed doubling 
time with DD- $\mathrm{A}_{2} \mathrm{pm}(4 \mathrm{~h})$ would only need to be $1.8 \mathrm{nmol} \mathrm{min}^{-1}(\mathrm{mg} \text { protein })^{-1}$. Preliminary attempts (unpublished) to detect conversion of $\mathrm{DD}-\mathrm{A}_{2} \mathrm{pm}$ to meso- $\mathrm{A}_{2} \mathrm{pm}$ with extracts of mutant SW2 have been unsuccessful, perhaps because of the very low enzymic activity that the organisms may have.

The wild-type organisms (B. megaterium 7581) can slowly take up DD- $\mathrm{A}_{2} \mathrm{pm}$ during growth (Day \& White, 1979). The mutant SW1 also probably takes up some DD-A $\mathrm{A}_{2} \mathrm{pm}$ when it grows on racemic (i.e. LL- and DD-) $\mathrm{A}_{2} \mathrm{pm}$. Saleh \& White (1976) found that culture filtrates of this mutant, after growth had stopped on limiting amounts of racemic $A_{2} p m$, always contained less residual $\mathrm{DD}-\mathrm{A}_{2} \mathrm{pm}$ than had originally been added to the medium in the racemate.

Certain amino acids may be enzymically altered after incorporation into peptidoglycan precursors (see review by Schleifer et al., 1976). Such a mechanism for production of the DD- $\mathrm{A}_{2} \mathrm{pm}$ that is in the wall of B. megaterium is unlikely (Day \& White, 1979). Finding $\left[{ }^{14} \mathrm{C}\right]$ lysine in the protein after growth of mutant SW2 with $\mathrm{DD}-\left[{ }^{14} \mathrm{C}\right] \mathrm{A}_{2} \mathrm{pm}$ proves that free $m e s o-\mathrm{A}_{2} \mathrm{pm}$ can be formed from DD- $\mathrm{A}_{2} \mathrm{pm}$. There is no unambiguous proof (Day \& White, 1979 ) that free meso- $\mathrm{A}_{2} \mathrm{pm}$ can be converted to free DD-A $\mathrm{pm}$. However, it seems uneconomical for organisms to have a separate system to catalyse this reaction, which (by analogy with the known reversibility of the enzyme LL-diaminopimelate 2-epimerase; White et al., 1969) might simply be the reversal of the DD- $\mathrm{A}_{2} \mathrm{pm}$ to meso- $\mathrm{A}_{2} \mathrm{pm}$ reaction.

Miss Lorna Young prepared $N$-acetyl-LL-diaminopimelate and extracted and assayed this compound from mutant SW1. Some of the assays for $\mathrm{N}$-acetyl-LL-diaminopimelate deacylase were done by Mr M. C. Evans. Amino acid analysis was done by Mrs Linda Gibb (Department of Biochemistry, University of Sheffield). We are very grateful to all these people.

\section{REFERENCES}

Bray, G. A. (1960). A simple efficient liquid scintillator for counting aqueous solutions in a liquid scintillation counter. Analytical Biochemistry 1, 279-285.

DAY, A. \& White, P. J. (1977). Enzymic assays for isomers of 2,6-diaminopimelic acid in walls of Bacillus cereus and Bacillus megaterium. Biochemical Journal 161, 677-685.

DAY, A. \& WhITE, P. J. (1979). Uptake of individual isomers of 2,6-diaminopimelate and their incorporation into walls during growth of Bacillus megaterium. Journal of General Microbiology 110, 401-407.

PARK, J. T. \& HANCOCK, R. (1960). A fractionation procedure for studies of the synthesis of cell-wall mucopeptide and of other polymers in cells of Staphylococcus aureus. Journal of General Microbiology 22, 249-258.

Rhuland, L. E., Work, E., Denman, R. F. \& HoARE, D. S. (1955). The behaviour of isomers of $\alpha, \epsilon$-diaminopimelic acid on paper chromatograms. Journal of the American Chemical Society 77, 4844-4846.

SALEH, F. \& White, P. J. (1976). Use of auxotrophic mutants to isolate LL- or DD-isomers of 2,6diaminopimelic acid. Journal of General Microbiology 96, 253-261.

Schleifer, K. H., Hammes, W. P. \& Kandler, O. (1976). Effect of endogenous and exogenous factors on the primary structures of bacterial peptidoglycan. Advances in Microbial Physiology 13, 245292.
Sundharadas, G. \& Gilvarg, C. (1967). Biosynthesis of $\alpha, \epsilon$-diaminopimelic acid in Bacillus megaterium. Journal of Biological Chemistry 242, 3983-3984.

Tempest, D. W., Meers, J. L. \& Brown, C. M. (1970). Influence of environment on the content and composition of microbial free amino acid pools. Journal of General Microbiology 64, 171-185.

WARD, J. B. (1975). Peptidoglycan synthesis in Lphase variants of Bacillus licheniformis and Bacillus subtilis. Journal of Bacteriology 124, 668-678.

White, P. J. (1971). Diaminopimelate decarboxylase (Escherichia coli). Methods in Enzymology 17B, 140-145.

White, P. J. (1972). The nutrition of Bacillus megaterium and Bacillus cereus. Journal of General Microbiology 71, 505-514.

White, P. J., Lejeune, B. \& Work, E. (1969). Assay and properties of diaminopimelate epimerase from Bacillus megaterium. Biochemical Journal 113, 589-601.

Wilkinson, B. J. \& White, P. J. (1973). The effect of antibiotics on synthesis of mucopeptide and teichoic acid by Pediococcus cerevisiae and by a substrain that requires methicillin for growth. Journal of General Microbiology 79, 195-204.

WoRK, E. (1957). Reaction of ninhydrin in acid solution with straight-chain amino acids containing two amino groups and its application to the estimation of $\alpha, \epsilon$-diaminopimelic acid. Biochemical Journal 67, 416-423.

Work, E. (1962). Diaminopimelate decarboxylase. Methods in Enzymology 5, 864-870. 